Talk on immigration and employment in the UK.

'Just an excuse people are just using these days': Attending to and managing interactional concerns in talk on exclusion of immigrants

\author{
Rahul Sambaraju ${ }^{1}$ \\ Chris McVittie ${ }^{2}$ \\ Karen Goodall ${ }^{3}$ \\ Andy McKinlay ${ }^{3}$
}

${ }^{1}$ University of Limerick, Ireland.

${ }^{2}$ Queen Margaret University, Edinburgh, UK.

${ }^{3}$ The University of Edinburgh, Edinburgh, UK.

Corresponding Author:

Rahul Sambaraju, Department of Psychology, University of Limerick, Ireland.

Email: Rahul.Sambaraju@ul.ie 
Talk on immigration and employment in the UK.

\begin{abstract}
In line with discursive work on the role of constructions of minority groups in social exclusion, we offer an examination of talk on immigrants and its links with employment of British residents, in the UK Parliament and interview talk with British residents looking for work, in the context of a financial crisis (2007-09). Discursive analysis of data shows that parliamentarians treat immigration as problematic for British residents' employment, whereas interviewees' responses reject or minimally accept this, while displaying sensitivity to the status of this as a prevalent complaint about immigration. Parliamentarians do so to warrant and challenge or manage challenges to Government's policies, whereas interviewees do so to manage being seen as discriminatory and workshy. These findings show that constructions of immigration and its links with employment in the context of the financial crisis, and, their use in warrants for exclusion are offered in ways to attend to the situated institutional and interactional relevancies in play for interlocutors.
\end{abstract}

\title{
Keywords
}

immigration; employment; UK; social exclusion; discourse analysis; financial crisis 
Talk on immigration and employment in the UK.

\section{'Just an excuse people are just using these days': attending to and managing interactional concerns in talk on exclusion of immigrants.}

Discursive social psychologists are interested in how descriptions of minority social groups such as immigrants, are constructed in talk to warrant their exclusion. Previous research shows that these warrants routinely involve constructing unfavourable versions of immigrants, in ways that ostensibly identify the problem with issues such as population increase or crime, rather than with immigration per se (Triandafyllidou, 2000; van Dijk, 1992). This elides implications of prejudice or racism, especially in contexts where these issues are readily salient. A prominent warrant involves attributing to immigrants responsibility for employment difficulties of residents of the arrival nation (Ipsos MORI, 2011; Rogers, Anderson, \& Clark, 2009). In this paper, we extend findings on this issue by examining how employment concerns are constructed as related, or not, to immigration and how interlocutors attend to, and manage these concerns. We focus on two distinct, but related settings: the UK House of Commons and interviews with British residents looking for work in the context of the most recent financial crisis (2007-09) in the UK.

Discursive studies of immigration have particularly examined talk by political elites such as parliamentarians (Rojo \& van Dijk, 1997), political leaders (Capdevila \& Callagahan, 2008), and media persons (Hanson-Easey \& Augoustinos, 2012) in settings such as parliaments, political speeches and media events. Studies examining talk of lay persons however have been rare (some noteworthy instances are: Gibson \& Hamilton, 2011; Goodman, 2010; Kirkwood, McKinlay, \& McVittie, 2013; Verkuyten, 2005). In both sets of studies, similar findings are noted. Talk about immigration routinely presents immigrants as the racial, ethnic, or cultural "other" (Reeves, 1983; Rojo \& van Dijk, 1997; Van der valk, 2003). However, describing immigrants in this way carries the risk that the speaker might be heard as prejudiced and speakers therefore work to manage implications of such talk 
Talk on immigration and employment in the UK.

(Augoustinos \& Every, 2007), for example through the use of disclaimers (Hewitt \& Stokes, 1975) such as, 'I'm not a racist, but...' (van Dijk, 1992). Alternatively, speakers may explicitly deny racism in warranting exclusion of immigrants (Goodman, 2010; Goodman \& Burke, 2011). Other ways of attending to this risk are to remove explicit mentions of race or ethnicity in talking about immigration, called 'discoursive deracialisation' (Reeves, 1983), through framing immigration as an issue of population size, national characteristics (Charteris-Black, 2006), or, social problems (van Dijk, 2000) rather than one of immigrants themselves. For instance, Capdevila and Callaghan (2008) show how Conservative political party members in the UK, attempted to justify limiting immigration by articulating specific concerns, without making explicit reference to race or ethnicity. These findings show how exclusion is accomplished without engendering ready accusations of prejudice and/or racism, and how explicit mentions of ethnic and racial descriptors are removed, suppressed, or, managed. Researchers identify these findings as constituting "new racism" (Augoustinos \& Every, 2007; Barker, 2001).

Discursive researchers show that concerns about employment are routinely used in talk about immigration. On the one hand, researchers show that immigrants are open to discrimination in employment (Barker, 2001; Essed, 1991; Omi \& Winant, 1986). On the other hand, researchers also examine how warrants for exclusion of immigrants are made on grounds that immigration has problematic effects on employment chances for residents of the arrival nation. This latter strand of work is directly relevant here. Van Dijk (2000) shows how political elites in parliamentary settings construct problematic versions of immigrants such as that immigrants are disposed to being unemployed and therefore a burden on the state (also see Van der Valk (2003)) or that immigrants would take up employment at lower wages and therefore lead to unemployment for residents of the arrival nation. 
Talk on immigration and employment in the UK.

In lay settings however, those who arguably experience employment issues articulate their concerns with immigration in diverse ways. In research interviews with high school children in northern England, Gibson (2011) shows how interviewees could rework issues of employment to treat immigrants as a problem for those in England and therefore warrant limits on or oppose immigration. In contrast, Triandafyllidou (2000), in an analysis of interviews with public officials, trade unionists, and, non-governmental officials in Spain, Italy, and, Greece, shows that although immigrants were usually presented in problematic ways, they were not blamed for employment concerns for residents of these nations. Instead, economy-related versions of immigration were used to explain discrimination and racist incidents. Greek interviewees however, did hold immigrants responsible for their issues with employment. While some of these findings are similar to those seen in elite settings, such as those of deracialisation and 'dodging the identity of prejudice' (Wetherell \& Potter, 1992), lay people employ diverse ways of justifying the exclusion of immigrants. Arguably then, interactional and institutional features are of particular relevance to examining these issues.

Discursive researchers have indeed examined how warranting and managing exclusion centrally involve features of interaction. Condor, Figgou, Abell, Gibson, \& Stevenson (2006) show how managing prejudice-in-talk is collaboratively accomplished by co-present interlocutors. Collaborative work between interlocutors plays a central role in the denial, mitigation, and, suppression of prejudice (Condor et al, 2006). Interlocutors can also counter prejudice by pointing to the problematic aspects of possibly prejudiced talk through certain conversational practices, like using extreme case (re)formulations (Robles, 2015) and features of preference organisation (Whitehead, 2015). LeCouter, Rapley, and, Augoustinos, (2001) show how Australian parliamentarians invoke and manage relevant issues of stake and interest (Potter, 1996) in negotiating warrants for policies that would be problematic for Aboriginal and Torres Strait Islander people in Australia. These findings show that speakers 
Talk on immigration and employment in the UK.

are alert to possible personal implications of prejudice and/or racism in warranting exclusion and attend to it in various ways in the interaction. Discursive social psychological research is centrally concerned with how implications of prejudice and/or racism are worked-up, oriented to, and managed in interactional settings (Durrheim, Greener, \& Whitehead, 2014). In line with this, we examined how speakers negotiate issues of immigration and orient to potential inferences in specific settings that embed particular language practices and interactional features.

We examined talk in two interactional settings: UK House of Commons and research interviews with British residents looking for work. We focused on a time frame when exclusion of immigrants was particularly relevant namely UK financial crisis which began in August 2007 (Edmonds, Jarrett, \& Woodhouse, 2010; The Guardian, 2012a, 2012b) and led to a notable rise in unemployment (British Broadcasting Corporation, 2012). In 2009, unemployment increased to 2.5 million and from there to 2.7 million, the highest in the previous 17 years, at the end of 2011 (Office for National Statistics, 2012). At this time, issues of unemployment were particularly relevant and, problematically, were attributed to immigrants, as seen in UK daily newspaper reportage (Rogers et al, 2009). One outcome of this is that these claims are likely to be seen as rhetorically less challengeable than at other times (Billig, 1987). What this means for the present study is that a readily recognised background of financial crisis makes available opportunities for policy-makers to readily treat immigration as an employment-related issue. For instance, UK policy-makers' discussions on immigration involved foregrounding the economic value of migrants into the UK in the formulation of the "points-based system" that was introduced in 2008 (Murray, 2011). A context of recession / high unemployment might also offer opportunities for those looking for

\footnotetext{
${ }^{1}$ Points-based system is an immigration policy introduced by the Labour Government in the UK in 2008 and still in effect. This involved allowing migrants entry into the UK for work or study on the basis of points scored. Points are calculated for their level of education, previous salary, levels of English language ability, and, age along with several other criteria depending of the type of stay sought in the UK. Under this scheme, unskilled labour-related migration from non-EU countries was stopped (Murray, 2011).
} 
Talk on immigration and employment in the UK.

work to readily orient to immigration issues in their accounts on employment. It is this that provides the focus for the present paper, where we examine how talk about employment concerns for British residents contributed to exclusion or inclusion of immigrants.

\section{Method}

\section{Data and participants.}

The data being examined are talk in the UK House of Commons and talk on employment and immigration with British interviewees looking for work.

Parliamentary data comprise transcripts of debates in the UK House of Commons between $1^{\text {st }}$ August 2007 and $31^{\text {st }}$ August 2009, since signs of contraction and subsequent relaxation in the economy ${ }^{2}$ were first officially noticed in this period (Edmonds et al., 2010). The transcripts were gathered from an online version of The Official Report of the proceedings of the House of Commons or the Hansard ${ }^{3}$ accessed on the World Wide Web through http://goo.gl/2X7cw4. Substantially verbatim transcripts of interactions are stored here as serially numbered Volumes, where each Volume contains transcripts of parliamentary proceedings like debates, written answers, and other interactions over a period of few days (the range was five to eleven days in our corpus). Search for the period specified returned 34 volumes (463 to 496), with discussions about issues of employment and migration occurring rather frequently during the period of the financial crisis. A random sampling method was used to select approximately one-third of the volumes (12) so that discussions about employment and migration throughout the official period of the crisis were equally open for analysis. These transcripts are unique in being prepared and maintained to stand as an official public record of parliamentary proceedings, in that, the transcription is done at the

\footnotetext{
${ }^{2}$ In addition to official recognition, British parliamentarians took-up these concerns in the House of Commons during this period.

3 'Hansard is a substantially verbatim report of what is said in UK Parliament. MPs' words are recorded and then edited to remove repetitions and obvious mistakes, albeit without taking away from the meaning" (UK Parliament, 2016).
} 
Talk on immigration and employment in the UK.

level of words and "filter[s] out spokeness" (Mollin 2007, Slembrouck 1992, p. 104), alongside certain editorial and grammatical polishing to enable a ready consumption by lay audiences. While this constrains the kinds of analyses possible, particularly those which attend to turn-by-turn features of interaction, these transcripts stand as a readily useable and referable public record of the happenings in a democratic parliament (Fitzgerald \& Housley 2009). Parliamentarians cite these transcripts to quote themselves and other parliamentarians from previous sessions (Antaki \& Leudar 2001). Similar to transcripts produced by other institutions as public records, these transcripts are social objects (McKinlay, McVittie \& Sambaraju 2011), and are open to analysis of how parliamentary talk accomplishes various policy actions. From this sub-sample relevant debates about immigration and employment were selected for further fine-grained analysis.

Interview data are transcripts of five semi-structured interviews with British residents who were looking for work in the UK on employment, the then ongoing financial crisis, and, immigration. Interviews were conducted in English by the first author, who is from India, between June 2011 and September 2011 outside a local JobCentre Plus ${ }^{4}$ in a Scottish city. Interviewer characteristics and the topic(s) of the interview make relevant particular issues of stake and interest and also limit the likelihood of offering particular accounts by interviewees (discussed in results). The interviewees ( 3 male and 2 female) had diverse educational qualifications ( 3 had tertiary education, 1 had secondary schooling and another had vocational training). Interviews involved discussions of available employment opportunities and interviewees' attempts to find work, the financial crisis, and then of immigration. In two of the five interviews, interviewees spontaneously mentioned immigration as being of relevance. Interviews were transcribed in accordance with an abbreviated version of the Jeffersonian system (Jefferson, 2004), which is commonly used in discursive research

\footnotetext{
${ }^{4}$ JobCentre Plus is a UK government agency under the Department for Work and Pensions. It provides jobsearch related services (JobCentreGuide, 2015).
} 
Talk on immigration and employment in the UK.

(Gibson, 2009; Kirkwood et al., 2013) as it affords analysis of the turn-by-turn accomplishment of actions by the interviewer and interviewee. These transcripts were read and re-read thoroughly before instances of talk that dealt with immigration and employment were selected for further fine grained analysis.

\section{Analytic procedure.}

These data were analysed using discursive approaches (McKinlay \& McVittie, 2008; Potter \& Edwards, 2001; Potter \& Hepburn, 2008), which treat discourse, spoken or written language in use, as a topic of study in its own right. Analysis proceeded by attending to how specific versions of events, agents and actions are constructed in discourse, their occasioned use in the interaction, and the social actions accomplished in their occasioned use. Discursive analysts approach discourse as having its own properties and features that allow for accomplishing specific social actions as part of social practices in specific settings. Since the settings here are distinct, we can expect specific institutional features (Drew \& Sorjonen, 1997) in the ways in which talk is organized, the social actions being accomplished and issues of what is at stake (Ilie, 2004; Potter \& Hepburn, 2005).

In Parliaments, debating, warranting and challenging or supporting policies are social practices (Potter \& Hepburn 2008). Analysis examined how parliamentary debates accomplished actions, such as treating immigration as problematic and warranting policies to address this 'problem'. Members of parliament routinely engage in practices such as asking questions of those in the Government, responding to these questions, and, stating a position in a debate (Condor, Tileagâ, \& Billig, 2013). The analysis took into account that specific immigration-related policy actions are embedded within these institutional actions.

Interviews are a highly specialized form of interaction (Potter \& Hepburn, 2005), which require the analysts to treat these as unique 'speech events' (Talmy, 2011), than as offering an unmediated access to interviewee perspectives (Condor, 2010). Here we examine 
Talk on immigration and employment in the UK.

particular speech events where the interviewer asked a pre-scripted question (delivered in differing ways in each instance): "do you think immigration has something/anything to do with employment?” Questions such as this, called 'yes/no interrogatives' (Raymond 2003), have particular implications for the interaction. Responses can be type-conforming (delivered as "yes", "no" or their variants) or non-conforming (any other response), respectively indicating whether the presupposition in the question (that immigration is one explanation for employment issues for British residents) is treated as plausible or not. Orienting to the presupposition as plausible can then involve, either an acceptance ('yes'involving) or a rejection ('no'-involving). The question design (Hayano, 2014, Raymond, 2003) can differentially prefer (Pomerantz, 1984), either an acceptance or a rejection. In addition, for the interactions being examined, since the interviewer is visibly / hearably an immigrant another means of orienting to what is preferred becomes relevant. A typeconforming acceptance that immigration is an explanation for employment issues for interviewees or British residents can be dispreferred because the interviewer is visibly / hearably a member of the group 'immigrants'. A non-conforming response might also jeopardize solidarity with the interviewer (Heritage, 1984) and lead to loss of 'face' (Pomerantz \& Heritage, 2012). The questions can also set-up cross-cutting preferences (Schegloff, 2007), to allow participants to manage issues that may be face-threatening. Analysis then examined how these issues of preference are oriented to and managed by interviewer and interviewees in interactions.

\section{Results}

In the first section we report findings from talk in the UK House of Commons.

\footnotetext{
${ }^{5}$ In the extracts presented here and in the data corpus we did not come across nonconforming responses.
} 
Talk on immigration and employment in the UK.

\section{Parliamentary talk.}

Here we examine extracts where parliamentarians treat immigration as problematic for

British residents. Extracts 1 and 2 were sourced from Volume 481 of Hansard, dated 21 October 2008. Here, the speakers were Anne Main a Conservative party MP, and, Jacqui Smith, Labour party MP and The Secretary of State for the Home Department.

\section{Extract 1.}

1 Main On the points-based system, would the Secretary of State like to comment on

9 Smith I am responsible for a lot of things, but I am not, thank goodness, responsible the fact that while her party is talking tough rhetoric over here, it was widely reported in the papers that at a conference in Sylhet led by the chair of the Home Affairs Committee, and attended by six Members, it was said that: "The number of Bangladeshis migrating to Britain would increase under the" points-based system? Which of the following is the points-based system: is it a method of control or a method of importing additional people into the country? for what the Chair of the Home Affairs Committee chooses to say-at home or abroad.

The points-based system has meant, for example, that we have been able to bar low-skilled workers from outside the EU. In fact, if tier 2 of the points system for skilled migrants had been in place last year, there would have been 12 per cent. fewer in this category coming here to work, and we now have detailed plans on the table, put forward by the independent migration advisory committee, to reduce by nearly one third the number of jobs available to migrants via the shortage occupation route. 
Talk on immigration and employment in the UK.

At lines 1-8, Main challenges the points-based system on grounds that it may not be limiting immigrants. She works-up a contrast which treats this as merely avowing limits on immigration and not actively limiting immigrants. She contrasts the Government's 'talking tough rhetoric' (line 2) in the UK Parliament and an alternative projected policy-outcome in a foreign institutional setting. This latter, directly reported (Holt, 1996) as an utterance at a meeting 'led by the chair of the Home Affairs Committee' (line 4) at lines 5-6, shows a Government representative to endorse the claim that migration from Bangladesh may 'increase' (line 6) under this system. Main treats 'talking tough rhetoric' as endorsing policies that would limit immigrants and therefore that, the contrasting outcomes claimed to have presented abroad amount to scoring mere political points. Main's question at lines 6-8 then treats the Government as not centrally committed to limiting immigrants: 'is it a method of control or a method of importing additional people into the country'. The descriptor 'additional people into the country' allows for hearing that migrants are possibly a burden for the UK and therefore policies should limit immigration rather than allow it. In this way, Main treats the Government as uncommitted to limiting immigrants.

Smith offers a two-part response. First, at lines 9-11, Smith downplays the relevance of another colleague's utterance for the ongoing interaction through a re-specification of footing (Goffman, 1981): she treats the 'Chair of the Home Affairs Committee' (line 12) as responsible for her/his own utterance. Second, she demonstrates the Government's commitment to limiting immigrants through the points-based system. She claims that this system has barred 'low-skilled workers from outside the EU' (line 2) and describes possible outcomes: 'if tier 2 of the points system for skilled migrants had been in place last year' (line 2-3) there would have been 12 per cent 'fewer' (line 4) skilled migrants in the country. She attributes an additional decrease in immigration to current policies because of this system: 
Talk on immigration and employment in the UK.

'nearly one third the number of jobs available to migrants' (lines 6-7). Smith, then, treats the Government's policies, like the points-based system, as committing to limits on immigration.

What we see in this extract is both parties treat limiting immigration as desirable, with Smith in her response taking up the inference made available by the question that doing so is needed to increase employment opportunities for UK citizens. The point at issue is not whether immigration should be limited but rather whether a 'points-based system' should be used to bring this about. In the next extract we also see parliamentarians negotiating the extent to which current Governmental policies limit immigration. The speakers here are Jacqui Smith and Chris Huhne, Liberal Democrat party MP.

\section{Extract 2.}

1 Smith: Does the hon. Gentleman not understand what I spelled out in my speech? 2 We have closed off tier 3 of the points-based system to reflect the impact of 3 inter-EU migration.

4 Huhne: I entirely accept that, but the Home Secretary also has to accept that her 5 Government, whom she has supported, have been in office for 11 years. 6 There were some 145,000 work-related non-EU migrants in 2006 and $7 \quad 124,000$ in 2007. Taken with the net immigration of non-EU migrants, that is a substantial flow. Its consequences have been unplanned and unforeseen.

At lines 1-2, Smith avows steps taken to implement policies that limit immigration, in response to Huhne's question on migration from EU countries (not shown): closing 'off tier 3 of the points-based system' (line 2). Huhne however, offers a criticism of the Government's immigration policies by showing that the Government are not effective in limiting immigration. This involves showing that in the last '11 years' (line 5) there has been a 
Talk on immigration and employment in the UK.

'substantial flow' of migrants into the UK. He specifically offers details on work-related immigration, which are that ' 145,000 work-related non-EU migrants in 2006' (lines 6-7) and ' 124,000 in 2007 ' (line 7), alongside references to alternative immigration, namely 'net immigration of non-EU migrants' (line 7). This shows that while the Government are implementing policies that limit immigration, previous policies have allowed immigration and therefore led to problems: consequences that are 'unplanned and unforeseen' (line 8). In not explicitly stating these problems, or who will be affected by them, Huhne avoids directly blaming immigrants for British residents' employment issues, while still indicating a favourable disposition towards limits on immigration. Again the need to limit immigration is treated as self-evidently desirable, with discussion focused on whether government policies are achieving this outcome.

In the last of the extracts here, we examine how parliamentarians treat commitment to and implementation of policies that limit immigration. Extract 3 was sourced from Volume 481 of the Hansard dated 27 October 2008. The speakers here are Mark Harper, Conservative party MP and Phil Woolas, Labour party MP and Minister of State for Border and Immigration.

\section{Extract 3.}

1 Harper: I thank the Minister for that answer. Is it not the case that, when he said that it has been too easy to get into this country in the past, he was right, and that is the reason for the failure of the Government's attempts at welfare reform? In the past three years, 365,000 fewer UK-born citizens were in work, while 865,000 more foreign migrants were in work. I listened to his answer ${ }^{6}$ to the

\footnotetext{
${ }^{6}$ The discussion shown below follows a debate opening question on "migration policy", specifically, on how ministerial colleagues co-ordinate on migration policy matters. In response, Woolas lists the various ministerial colleagues involved and the nature of co-ordination.
} 
Talk on immigration and employment in the UK.

8 Woolas No, I do not accept that. If the hon. Gentleman is fair- I know that he is-

that he announced, are they not too little, far too late? he will examine the policies of a range of Departments, including the changes that have been introduced today to incapacity benefit to help the welfare-to-work programme. Of course, the needs of the economy are being put first, as he says, by the points-based system. I therefore disagree with him-I believe that the steps will be sufficient

Through claims that the Government failed at 'welfare reform" (line 3), Harper treats the Government as altogether ineffective since its policies have allowed immigration at the expense of addressing employment issues for British residents. He offers numeric information that treats this as readily knowable (Potter, 1996). First, Harper attributes the 'failure of the Government's attempts at welfare reform' (line 3) to policies on immigration: 'too easy to get into this country in the past' (line 2). Second, he presents this as resulting in a loss of employment opportunities for British residents, alongside gains in employment for migrants: '365,000 fewer UK-born citizens' and ' 865,000 more foreign migrants' were in work. This offers the inference that transition of British residents from being unemployed, and on welfare, to being employed was undermined due to policies allowing unrestricted immigration. While Harper concedes that ongoing or recent amendments to migration policies - 'steps that he announced" (lines 6-7) - are being put in place by the Government, his earlier descriptions allow for treating these as ineffective: 'too little, far too late' (line 8). In this way, Harper treats the Government as committed to policies that limit immigration, while treating the Government as failing to implement these policies. In so doing, Harper

\footnotetext{
7 The Welfare Reform Act 2007 had the stated aim of increasing benefit claimant's motivation to seek employment (Marshall-Ascough, 2014; "Welfare Reform Act 2007," 2007)

${ }^{8}$ As seen in the earlier extracts Woolas' Ministry had announced the introduction of a points-based system and/or policies that would change citizenship opportunities for those who migrate to the UK for work on October 21, 2008 (Murray, 2011).
} 
Talk on immigration and employment in the UK.

treats this Government as altogether ineffective for its complacency in implementing policies that would limit immigration and address employability of British residents.

In response, Woolas rejects and undermines Harper's unfavourable evaluation of the Government. First, he rhetorically works-up Harper's claims as inaccurate through claims that Harper was selectively ignoring policies designed to specifically address the issues raised, such as the 'incapacity benefit to help the welfare-to-work programme' (line12). Woolas presents ongoing efforts as addressing employment for British residents through avowals of support for this programme. Second, he characterizes the 'points-based system' (line 13) as addressing 'the economy' (line 13) through offering an alternative inference on immigration into the UK: migrant workers are addressing economic issues for the UK. By ascribing this to Harper, Woolas undermines Harper's problematic claims that the Government's policies are designed to ignore British residents' employment needs, in favour of allowing immigration. In their accounts, both parliamentarians treat policies that limit immigration as desirable, while negotiating the extent to which current policy implementation attend to limiting immigration and its consequences.

In these extracts, parliamentarians, in the Government and Opposition, orient to immigration as being problematic by way of its consequences for employment: immigrants arriving in the UK take up work there. Limiting immigration as a means of restricting nonUK nationals in work thus becomes a desirable and accepted policy, in challenging or managing challenges to Government's functioning. This was done through presenting policy-outcomes as adequate or not in this regard. Parliamentarians treated not limiting immigration as detrimental to employment chances for British residents, without directly or explicitly problematizing immigrants. Parliamentarians could thus render their policy-

\footnotetext{
${ }^{9}$ Since the 1990s several nations introduced schemes that would limit Government welfare spending and increase benefit claimants' motivations to seek employment. Similar measures were taken by the UK government in 1997 and then in 2007, including changes to "Disability benefits" and "housing schemes" (Employment Related Services Association, n.d).
} 
Talk on immigration and employment in the UK.

actions as legitimate. Below, we examine how those supposedly facing employment issues discuss immigration and their employment chances in the context of this financial crisis.

\section{Interview accounts.}

Here the focus is on how interviewees orient to immigration as a candidate account for their or British residents' employment issues, offered in a yes/no interrogative format (Raymond, 2003). Given the arguments in the extracts above it is possible that interviewees might also endorse claims for the consequences of immigration for decreased employment opportunities for British residents. However, since the interviewee was visibly / hearably an immigrant, the interviewees might not readily endorse claims against members of that category. Here, specific features of the setting such as interviewing those looking for work outside JobCentre Plus, make relevant particular issues of stake (Potter, 1996) for interviewees, such as that of accounting for their (un)employment status (cf. McVittie, McKinlay, \& Widdicombe, 2008) and selecting appropriate accounts in doing so. While this phenomenon was seen throughout the interviews, we examine three instances of how these issues are managed. The first two extracts show interviewees attending to these concerns made relevant by the interviewer's question, whereas in the third, interviewee introduces immigration as a potential account and subsequently offers a mitigated acceptance.

In the first of the extracts Participant 6 minimally rejects the account that immigration mediates employment issues for British residents. Participant 6 is a female British resident who had been looking for work for 5 months at the time of this interview.

\section{Extract 4.}

1 Interviewer: and. eh $>$ do you think $<$ immigration has anything to do with

2

3 Participant 6: not really

4 Interviewer: (yea) 
Talk on immigration and employment in the UK.

5 Participant 6: i think. a >lot of people $<$ using that just=to as an excuse

6 Interviewer: yea

7 Participant 6: i think (0.7) it's ((muffled)) it's really difficult cos (2.4) it doesn't 8 matter how many people are in the country

9 Interviewer: yea

10 Participant 6: it doesn't matter cos like job opportunities are still equal to anyone and 11 everyone

12 Interviewer: yea

13 Participant 6: especially when you got the trai:ning if you've not got the training

14 Interviewer: yea

15

16 Participant 6: so: i don't really think i think just an excuse people are just using these 17 days

While the polarity and grammar of the question together prefer a type-conforming rejection, Participant 6 offers a mitigated negative response, which falls short of being a ready rejection: 'not really' (line 3). The interviewee then is hearable as resisting the plausibility of the terms in the question, in particular, she delays accepting or rejecting the claim in the question. Here, accepting the terms is problematic for its implications on the ongoing interaction with the interviewer and rejecting involves searching and offering another account for issues with employment. She manages the interactional implications of this through undermining complaining about being unemployed (Edwards, 2005). This is prompted by the interviewer's uptake and orientation to her mitigated negative response, delivered as a soft '(yea)' (line 4), as relevantly incomplete. Participant 6's explication attends to her mitigated orientation to the presupposition in the question, which is that the claims offered are used 'just=to as an excuse' (line 5) by an unspecified 'lot of people' (line 5). 
Talk on immigration and employment in the UK.

Participant 6 offers an alternative version of issues with employment at lines 7-13 as a counter argument to those making these claims. She rejects candidate accounts such as immigration and, interestingly, skill levels for problems with employment through a particular characterization of employment: 'job opportunities are still equal to anyone and everyone' (lines 10-11). The extreme case formulations (Pomerantz, 1986) 'anyone' and 'everyone' legitimize her claim that the availability of employment opportunities is not contingent on immigrants or on the skill levels of those who are looking for work (cf. Augoustinos et al., 2005). The latter is particularly introduced as relevant to the characterisation of employment: 'especially when you got the trai:ning if you've not got the training' (line 13). Her introduction and rejection of skill levels as a possible candidate account, together with her account on employment undermine complaints about being unemployed. Her subsequent restatement negates the above possible candidate accounts for issues with employment: 'just an excuse people are just using these days' (lines 16-17). It is notable that this is similarly soft as her earlier proposition in treating these claims as temporally contingent to 'these days'. Her account neither accepts nor rejects immigration as a candidate account, but offers an alternative version of the terms in the question, which is that complaints about one's employment issues are illegitimate, irrespective of whether the complaint is made out as about immigration or other matters.

One point of note in the extract above is that Participant 6 makes no reference to her own employment status or experiences. Instead she responds in terms of an unspecified group ('lot of people') or using the generalised 'you' (Sacks, 1992, vol. 1, 163-168) to suggest that she is describing a general state of affairs rather than anything specific to her as an individual. In the next extract, we see Participant 4 responding to a yes/no interrogative that explicitly refers to his personal circumstances. Participant 4 is a male British resident who had been 
Talk on immigration and employment in the UK.

looking for work for about 7 months at the time of the interview. Prior to the interaction shown below he had rejected claims that immigration mediates chances for employment.

\section{Extract 5.}

1 Interviewer: i mean=your employment opportunities you don do you think they have changed because o:f (.) immigration

3 Participant 4: no. not at all (.) I think the recession was gonna happen anyway

4 Interviewer: yea

5 Participant 4: may=maybe if there were less people here from other countries there 6 would be:

7 Interviewer: yea

8 Participant 4: $\quad$ more space for jobs but. (.) $>\uparrow$ then again < people would > still not put in no $\uparrow$ effort and probably not get them anyway< so

10 Interviewer: yea

11 Participant 4: just because they are comin here and tryin for the jobs doesn't mean we 12 should blame them (.) i $\uparrow$ don't think it makes a difference now

At lines 1-2, the interviewer repairs his question from a no-preferring interrogative ('you don') to a yes-preferring interrogative: 'do you think'. Given the interviewee's earlier rejection of immigration as an account, this repair allows the interviewee to offer his response anew with regards to his own employment issues. However, the action-preference set-up is that the interviewee reject the explicit claim that his employment chances are affected 'because' of immigration for reasons of maintaining interactional solidarity and particularly when it is likely that an acceptance maybe heard as blaming others for his issues with employment. These cross cutting (Schegloff, 2007) preferences attend to possible issues of losing face (Schegloff, 1988): the interviewer would not want to come-off as ascribing an anti-immigrant attitude to the interviewee and at the same time not assume a "safe" view on 
Talk on immigration and employment in the UK.

behalf of the interviewee, given the earlier (not shown) rejection. Participant 4's rejection at line 3 - 'no. not at all' (line 3) - in using the extreme case formulation (Pomerantz, 1986) treats his position as readily knowable and as disposed to not blaming immigrants for his issues with employment. His reference to the inevitability of the financial crisis attends to the reason for his rejection: 'the recession was gonna happen anyway' (line 3). This, together with what follows is delivered as a three-part show concession (Antaki \& Wetherell, 1999) at lines 3 through 12, in ways to reaffirm his position as someone who would not blame immigrants. The first part is his rejection at line 3, the second part is a concession to the possible benefits in having fewer working migrants and the third reprisal is a rejection of the concession that shows immigration as irrelevant for employment concerns for British residents and the subsequent restatement of his initial position. Participant 4's description of probable state of affairs that 'less people here from other countries' (line 5) might make for 'more space for jobs' (line 8), concedes that immigration maybe a potential account for employment issues for those who are already 'here' (cf. Billig, 1995). The third part, which is a restatement of the first, offered at lines 8 through $12-$ 'but. (.) $>\uparrow$ then again $<$ people would > still not put in no $\uparrow$ effort and probably not get them anyway< so' - negates claims on possible role of immigration by offering an alternative explanation for employment, namely through 'effort' (line 9) and 'tryin for the jobs' (line 11). Participant 4 attributes these employment-gaining activities to people who 'are comin here' (line 11) and points to the absence of these activities on the part of an unspecified 'people' (line 8), hearable as referring to immigrants and British residents respectively. His response orients to the plausibility of blaming immigrants and rejects it, using a show concession format that involves offering a particular version of gaining employment, namely through 'effort' and the relevance of the financial crisis. This serves to reject immigration as an account for employment issues. 
Talk on immigration and employment in the UK.

The last of the extracts analysed here shows a deviation from the above two extracts in non-trivial ways: first, Participant 5 herself introduces immigration as a potential account for issues with employment, which raises the issue of breaching interactional solidarity. Second, she offers a mitigated acceptance of the claim embedded in the question, partly as a consequence of her earlier introduction. Participant 5 is a female British resident who had been looking for work for the last 9 months at the time of the interview. Prior to the interaction shown below, the interviewee had been discussing her problems with finding employment and the wider employment situation.

\section{Extract 6.}

1 Interviewer: a:nd d'you think it's: why do you think that is

2

3 Participant 5: i think there there's just so many people looking for work $\downarrow$ and like

5

6 Interviewer:

7

8 Participant 5:

10 Interviewer: yea

11 Participant 5: bu:t (.) then again they take up (.) >they take jobs that we won't $<$

12 Interviewer: yea

13 Participant 5 ehm yea (.) a bit of both really

At line 1, the interviewer repairs his question to shift its action-trajectory mid-way from initiating an acceptance / rejection as a response to an account-inviting question: from a specified 'd'you' to an open wh-prefaced question: 'why' (line 1). The question then allows 
Talk on immigration and employment in the UK.

for a discussion of possible accounts for unemployment than an acceptance / rejection of a candidate account. Participant 5 offers two accounts of competition. The first is: 'there's just so many people looking for work' (line 3). In many ways this serves to account for problems in finding employment. However, she goes onto offer a second account, at lines 4-5, which is expressly indexed as such as through the use of the conjunction 'and' (line 3). This account on 'everyone from different countries' (line 4) similarly makes relevant competition, but particularly from migrants. By using the extreme case formulated (Pomerantz, 1986) description, Participant 5 legitimizes treating immigrants looking for work as an account for issues with finding employment generally. This however raises the issue of problematizing the ongoing interviewer-interviewee interaction.

Given this account, the interviewer's next question, at lines 6-7, sets-up a typeconforming acceptance of the account that immigration affects British residents' chances of employment, in other words the question sets-up an explanation for her earlier ascription of issues to immigrants. Participant 5 offers a hedged acceptance that is followed by the particle 'u:hm' (line 8): 'in a way yea' (line 8). This treats her acceptance as a dispreferred response (Schegloff, 2010), particularly since her account implicates immigrants, such as the interviewer, in employment issues for Scottish / British residents. While the interviewer's question sets-up a response where the interviewee can offer an explanation for implicating immigrants, her response orients to her oncoming explication as possibly problematic for precisely these implications. The interviewee's response therefore displays sensitivity across descriptions from lines 8-11: the first treats it as readily available - 'obviously' (line 8) - that employment activities of migrants, such as that 'trying to get jobs' (lines 8-9), lead to employment issues for 'Scottish people' (line 9), and, therefore as possibly problematic. The second, subsequent to the interviewer's agreement / continuer, offered as a contrast with the first - 'but then again' - ascribes alternative employment activities to migrants: 'they take up 
Talk on immigration and employment in the UK.

(.) $>$ they take jobs that we won' $t<$ '. This negates possible inferences that migrants may adversely affect employment for Scottish / British residents by categorizing employment taken up by migrants as that which is unlikely to be taken up by Scottish / British residents. These contrasting descriptions of migrants' employment activities and their effects on employment for British residents are summarised as: 'a bit of both really' (line 13). Participant 5 avoids problematizing immigrants and engendering accusations of being antiimmigrant, and therefore jeopardizing interactional solidarity with the interviewer, while offering an explanation for possible issues with employment.

So, interviewees display sensitivity to accepting immigration as a candidate account for their employment issues as offered by the interviewer or themselves. This is particularly done in ways to avoid jeopardizing ongoing interaction with the interviewer, while attending to the issue of "how to account for employment issues". Interviewees manage this through indicating dispreferrence in accepting immigration as an account and offering alternative accounts of employment and immigration.

\section{Discussion}

In this paper we examined how versions of immigration as bound-up, or not, with employment outcomes for British residents were oriented to, and managed, in two interactional settings: parliamentarians' talk in the UK House of Commons and interview talk of British residents looking for work in the UK in the context of a financial crisis. Findings show that formulations of, and orientations to, how immigration may or may not be bound-up with employment attend to managing concerns that become relevant through the linguistic and social practices in these settings. In parliamentary talk we not only see an unproblematic use of a recognised complaint about immigration, namely that it adversely affects employment for British residents but also the acceptance that this is desirable. Parliamentarians challenge and manage challenges to the Government in their abilities and 
Talk on immigration and employment in the UK.

commitment to implementing policies that limit immigrants. In interview talk, interviewees attend to concerns over readily accepting this complaint while orienting to its plausibility as an explanation for employment issues.

Previous findings show that parliamentarians treat immigration as a problem for employment to their polity in warranting exclusion of immigrants (Capdevila \& Callagahan, 2008; Reeves, 1983; van Dijk, 2000). Here however, parliamentarians used similar versions of immigration without explicitly problematizing immigrants. Rather, they cast the issue as that of employment for British residents and policy-actions that can address or further deteriorate this. Parliamentarians used this version to treat employment for British residents as central to their activities as parliamentarians in, for example, criticising the workings of the Government. Responses to these critiques were met by demonstrating and reiterating a commitment to addressing unemployment by limiting immigration. Parliamentarians maintained and promoted the complain-able status of immigration, without offering explicit derogatory versions of immigrants. Parliamentarians' actions accomplished political goals such as those of taking on and addressing issues that are purportedly experienced by the national polity, showing-up those in the opposite side of the Parliament, and, demonstrating that they are fulfilling their roles as parliamentarians ( $c f$. Ilie, 2004).

Findings show that those who purportedly face issues with employment, that is the interviewees, minimally reject, reject or minimally accept this version of immigration and warrants for exclusion of immigrants. In giving type-conforming responses (Raymond, 2003), interviewees orient to the plausibility of treating immigration as an explanation for their or British residents' issues with employment, through avowing possible competition and numbers of immigrants. However, a ready acceptance might jeopardize the ongoing interaction since the interviewer is visibly / hearably an immigrant. At the same time, any such claim might be treated as reflecting interviewee's stake in producing an account for his / 
Talk on immigration and employment in the UK.

her unemployment and dismissed on such grounds (McVittie. et al., 2008). To manage this, interviewees oriented to these purported claims as a prevalent complaint in their rejection or minimal acceptance of these ('just an excuse' in Extract 4 and 'we can blame them' in Extract 5) or offered a minimal negative response in ways to offer an altogether alternative version of the claims in the question, so as not to jeopardize the interviewer-interviewee relationship. Their responses were formulated as deliberations, through concessions (Antaki \& Wetherell, 1999) for instance, than as mere parroting of some standard opinions. Interviewees, then, displayed sensitivity in treating immigration as a plausible account for their issues with employment.

Interviewees' responses involved alternative accounts for employment issues, such as individual effort (Gibson, 2009; McVittie. et al., 2008) or readily recognisable external circumstances like the financial crisis. Their talk thus differed both from that of parliamentarians and from lay talk found in previous studies (cf. Gibson, 2011). In this way, interviewees attended to other issues of stake in treating immigration as a potential reason for unemployment, since blaming immigrants would invite the implication that the interviewees are not very willing to put in the effort or take on the competition. What then seems to be at play, is resisting being seen as 'work-shy' (Gibson, 2009) and as those who do not want to appear as discriminating (Goodman, 2010; Goodman \& Burke, 2011). While researchers note that in certain lay settings, immigrants may not be blamed for employment problems (Triandafyllidou, 2000), we also see that this is done in orienting to blaming immigrants as a problematic and prevalent complaint. Interviewees show that they attend to their situation not only as those looking for work, and/or as those who may be facing issues with employment, but also as those who are the majority in this context. This orientation to immigration in interviews with a perceivably foreign national allowed interviewees to present themselves as welcoming residents and as residents who do not hold antipathy towards 
Talk on immigration and employment in the UK.

immigrants and their employment activities. Research shows how minorities, or, those who may be expected to face discrimination, deny discrimination (Verkuyten, 2005) or display trouble in avowing being discriminated against for reasons of not jeopardizing their hosts or their stay in another country (Kirkwood, McKinlay, \& McVittie, 2012). Here, interviewees' accounts serve to present themselves as those who neither hold grievances against immigrants nor endorse routine complaints regarding employment issues, but rather as majority polity who do not discriminate against minorities. This is made particularly deliverable in interviews where a readily known (Rogers et al, 2009; Ipsos MORI, 2011) discriminating argument or trope, such as that 'immigrants take "our" jobs', is in play.

While, parliamentarians mobilise certain versions of immigration and its effects on employment to engage in policy actions, lay individuals are more concerned with accounting for their own circumstances in ways that are not readily open to challenge. For them, explaining being unemployed in terms of immigrants coming into the UK raises issues of stake, and potentially of prejudice, that are not immediately relevant for those in employment or indeed in the parliament. These findings demonstrate how speakers utilise different versions of the relationship of immigration to employment possibilities in order to meet the requirements of the local and institutional settings within which they attend to these issues. Ways of managing implications of prejudice (Augoustinos \& Every, 2007) then involve speakers orienting to the local institutional and interactional contexts, where wider aspects such as the financial crisis and its outcomes are strategically used. Future studies that examine social exclusion can usefully attend to the development and management of issues of prejudice, or other concerns in the interaction in adding to findings on "new racism" (Barker, 2001). 
Talk on immigration and employment in the UK.

\section{References}

Antaki, C., \& Wetherell, M. (1999). Show Concessions. Discourse Studies, 1(1), 7-27. doi: $10.1177 / 1461445699001001002$

Augoustinos, M., \& Every, D. (2007). The language of "Race" and "Prejudice": A discourse of denial, reason, and liberal-practical politics. Journal of Language and Social Psychology, 26(2), 123-141.

Augoustinos, M., Tuffin, K., \& Every, D. (2005). New racism, meritocracy and individualism: Constraining affirmative action in education. Discourse \& Society, 16(3), 315-340.

Barker, M. (2001). The New Racism. London: Junction Books.

Billig, M. (1987). Arguing and thinking: A rhetorical apporach to social psychology. Cambridge: Cambrdige University Press.

Billig, M. (1995). Banal Nationalism. London: Sage.

British Broadcasting Corporation. (2010). Global recession timeline. Retrieved 21 November, 2014, from http://news.bbc.co.uk/2/hi/business/8242825.stm

British Broadcasting Corporation. (2012). Economy tracker: Unemployment. Retrieved 21 November, 2014, from http://www.bbc.co.uk/news/10604117

Capdevila, R., \& Callagahan, J. E. M. (2008). 'It's not racist. It's commonsense'. A critical analysis of political discourse around asylum and immigration in the UK. Journal of Community \& Applied Social Psychology, 18, 1-16. doi: 10.1002/casp.904

Charteris-Black, J. (2006). Britain as a container: Immigration metaphors in the 200 election campaign. Discourse \& Society, 17(5), 563-581. doi: 10.1177/0957926506066345 
Talk on immigration and employment in the UK.

Condor, S. (2010). Sense and sensibility: The conversational etiquette of English national self-identification. In A. Aughey \& C. Berberich (Eds.), These Englands: A Conversation on National Identity. Manchester: Manchester University Press.

Condor, S., Figgou, L., Abell, J., Gibson, S., \& Stevenson, C. (2006). 'They're not racist...' Prejudice denial, mitigation and suppression in dialogue. British Journal of Social Psychology, 45, 441-462. doi: 10.1348/014466605X66817

Condor, S., Tileagâ, C., \& Billig, M. (2013). Political Rhetoric. In L. Huddy, D. O. Sears \& J. S. Levy (Eds.), The Oxford Handbook of Political Psychology. Oxford: Oxford University Press.

Drew, P., \& Sorjonen, M. L. (1997). Institutional Dialogue. In T. van Dijk (Ed.), Discourse as Social Interaction: Discourse Studies: A Multidisciplinary Introduction (pp. 92118). London: Sage.

Durrheim, K., Greener, R., \& Whitehead, K. A. (2014). Race trouble: Attending to race and racism in online interaction. British Journal of Social Psychology, 54(1), 84-99. doi: 10.1111/bjso. 12070

Edmonds, T., Jarrett, T., \& Woodhouse, J. (2010). The credit crisis: a timeline. House of Commons Library, UK: London.

Edwards, D. (2005). Moaning, whinging and laughing: the subjective side of complaints. Discourse Studies, 7, 5-29.

Employment Related Services Association. (n.d). A brief history of welfare to work in the UK. Retrieved 03 July, 2016, from http://ersa.org.uk/media/history.

Essed, P. (1991). Understanding Everyday Racism. Newbury Park, California: SAGE.

Figgou, L., \& Condor, S. (2006). Irrational Categorization, Natural Intolerance and Reasonable Discrimination: Lay Representations of Prejudice and Racism. British Journal of Social Psychology, 45, 219-243. 
Talk on immigration and employment in the UK.

Gibson, S. (2009). The Effortful Citizen: Discursive Social Psychology and Welfare reform. Journal of Community and Applied Social Psycholog., 19, 393-410.

Gibson, S. (2011). Dilemmas of citizenship: Young people's conceptions of un/employment rights and responsibilities. British Journal of Social Psychology, 50(3), 450-468.

Gibson, S., \& Hamilton, L. (2011). The rhetorical construction of polity membership: Identity, culture and citizenship in young people's discussions of immigration in northern England. Journal of Community \& Applied Social Psychology, 21(3), 228242.

Goffman, E. (1981). Forms of talk. Oxford: Basil Blackwell.

Goodman, S. (2010). "It's not racist to impose limits on immigration": Constructing the boundaries of racism in the asylum and immigration debate. Critical Approaches to Discourse across Disciplines, 4, 1-17.

Goodman, S., \& Burke, S. (2011). Discursive deracialization in talk about asylum seeking. Journal of Community \& Applied Social Psychology, 21(2), 111-123. doi: 10.1002/casp.1065

Hanson-Easey, S. A., \& Augoustinos, M. (2012). Narratives from the neighbourhood: The discursive construction of integration problems in talkback radio1. Journal of Sociolinguistics, 16(1), 28-55. doi: 10.1111/j.1467-9841.2011.00519.x

Heritage, J. (1984). Garfinkel and ethnomethodology. Cambridge, England: Polity.

Hewitt, J. P., \& Stokes, R. (1975). Disclaimers. American Sociological Review, 40, 1-11.

Holt, E. (1996). Reporting on Talk: the use of Direct Reported Speech in Conversation. Research on Language and Social Interaction, 29(3), 219-245.

Ilie, C. (2004). Insulting as a (un)parliamentary practice in British and Swedish parliaments: A rhetorical approach. In P. Bayley (Ed.), Cross-cultural Perspectives on Parliamentary Discourse (pp. 45-86). Amsterdam: John Benjamins. 
Talk on immigration and employment in the UK.

Ipsos MORI. (2011) Strong support for a cap on immigration amidst economic concern. Retrieved $10 \quad$ August, 2012, from http://www.ipsosmori.com/newsevents/latestnews/644/Strong-support-for-a-cap-on-immigrationamidst-economic-concern.aspx

Ipsos MORI (2012a). Attitudes Towards Immigration. Retrieved 10 August, 2012, from http://www.ipsos-mori.com/researchpublications/researcharchive/53/AttitudesTowards-Immigration.aspx?view=wide.

Ipsos MORI. (2012b). Survey reveals negative attitudes to immigration. Retrieved 10 August, 2012, from http://www.ipsosmori.com/researchpublications/researcharchive/2972/Global-dvisor-Survey-revealsnegative-attitudes-to-immigration.aspx

Jefferson, G. (2004). Glossary of transcription symbols with an introduction. In G. H. Lerner (Ed.), Conversation Analysis: Studies from the first generation (pp. 13-23). Philadelphia: John Benjamins.

JobCentreGuide. (2015). What is the JobCentre Plus? Retrieved 08 April, 2015, from http://www.jobcentreguide.co.uk/jobcentre-plus-guide/4/what-is-the-jobcentre-plus

Kirkwood, S., McKinlay, A., \& Chris, M. (2013). 'Some people it is very difficult to trust': Attributions of agency and accountability in practitioners' talk about integraion. Journal of Community \& Applied Social Psychology, 24(5), 376-389. doi: $10.1002 /$ casp. 2178

Kirkwood, S., McKinlay, A., \& McVittie, C. (2012). 'They are more than animals': Refugees' accounts of racially motivated violence. British Journal of Social Psychology, 52(4), 747-762. doi: 10.1111/bjso. 12007 
Talk on immigration and employment in the UK.

LeCouter, A., Rapley, M., \& Augoustinos, M. (2001). 'This very difficult debate about Wik': Stake, voice and management of category memberships in race politics. British Journal of Social Psychology, 40, 35-57. doi: 10.1348/014466601164687

Marshall-Ascough. (2014). The Hypocrisy of the Labour Party on Welfare Reform. Retrieved 03 July, 2016, from http://www.huffingtonpost.co.uk/Liam-MarshallAscough/hypocrisy-of-labour-welfar-reform_b_5234607.html

McKinlay, A., \& McVittie, C. (2008). Social Psychology \& Discourse. Sussex: WIleyBlackwell.

McKinlay, A., McVittie, C., \& Sambaraju, R. (2011). 'This is ordinary behaviour': categorization and culpability in Hamas leaders' accounts of the Palestinian/Israeli conflict. British Journal of Social Psychology, 51(4), 534-550. doi: 10.1111/j.20448309.2011.02021

McVittie, C., McKinlay, A., \& Widdicombe, S. (2003). Committed to (un)equal opportunities?: 'New ageism' and the older worker. British Journal of Social Psychology, 42(4), 595-612. doi: 10.1348/014466603322595293

McVittie, C., McKinlay, A., \& Widdicombe, S. (2008). Passive and active non-employment: Age, employment and the identities of older non-working people. Journal of Aging Studies, 22(3), 248-255. doi: http://dx.doi.org/10.1016/j.jaging.2007.04.003

Mehan, H. (1997). The Discourse of the Illegal Immigration Debate: A Case Study in the Politics of Representation. Discourse \& Society, 8(2), 249-270. doi: $10.1177 / 0957926597008002006$

Murray, A. (2011). Britain's points based migration system. London: CentreForum.

Office for National Statistics, (2012). Migration Statistics Quarterly Report August 2012. Retrieved from 
Talk on immigration and employment in the UK.

http://www.ons.gov.uk/ons/rel/migration1/migration-statistics-quarterlyreport/august-2012/msqr.html

Omi, M., \& Winant, H. (1986). Racial Formation in the United States: From the 1960s to the 1980s. New York: Routledge and Kegan Paul.

Pomerantz, A., \& Heritage, J. (2012). Preference. In J. Sidnell \& Stivers.T (Eds.), The Handbook of Conversation Analysis (pp. 210-228). Chister, West Sussex: John Wiley \& Sons, Ltd.

Pomerantz, A., \& Zemel, A. (2003). Perspectives and frameworks in interviewers' queries. In H. van den Berg, M. Wetherell \& H. Houtkoop-Steenstra (Eds.), Analyzing Race Talk: Multidisciplinary Perspectives on the Research Interview (pp. 215-231). Cambridge: Cambridge University Press.

Pomerantz, A. M. (1986). Extreme case formulations: a way of legitimizing claims. Human Studies, 9, 219-230.

Potter, J. (1996). Representing Reality: Discourse, rhetoric and social construction. London: Sage.

Potter, J. (1996). Representing reality: Discourse, rhetoric and social construction (Vol. null).

Potter, J., \& Edwards, D. (2001). Discursive social psychology. In W. P. Robinson \& H. Giles (Eds.), (pp. 103-118). Chichester: Wiley. (Reprinted from: Not in File).

Potter, J., \& Hepburn, A. (2005). Qualitative interviews in psychology: problems and possibilities. Qualitative Research in Psychology, 2, 1-27.

Potter, J., \& Hepburn, A. (2008). Discursive constructionism. In J. A. Holstein \& J. F. Gubrium (Eds.), Handbook of constructionist research (pp. 275-293). New York: Guildford. 
Talk on immigration and employment in the UK.

Raymond, G. (2003). Grammar and Social Organization: Yes/No Interrogatives and the Structure of Responding. American Sociological Review, 68(6), 939-967. doi: $10.2307 / 1519752$

Reeves, F. (1983). British racial discourse: A study of British political discourse about race and race-related matters. Cambridge: Cambridge University Press.

Robles, J. S. (2015). Extreme Case (Re)formulation as a Practice for Making Hearably Racist Talk Repairable. Journal of Language and Social Psychology, 34(4), 390-409. doi: $10.1177 / 0261927 \times 15586573$

Rogers, A., Anderson, B., \& Clark, N. (2009). Recession, vulnerable workers and immgiration: background report.

Rojo, M. L., \& van Dijk, T. A. (1997). Legitimating the Expulsion of `Illegal' Migrants in Spanish Parliamentary Discourse. Discourse \& Society, 8(4), 523-566. doi: $10.1177 / 0957926597008004005$

\section{Sacks, H. (1992). Lectures on Conversation, edited by G. Jefferson. Oxford: Blackwell.}

Schegloff, E. (1988). Goffman and the analysis of conversation. In P. Drew \& A. Wootton (Eds.), Erving Goffman: Exploring the Interaction Order. Cambridge: Polity Press.

Schegloff, E. A. (2007). Sequence organization in interaction: a primer in conversation analysis (Vol. 1). Cambridge: Cambridge University Press.

Talmy, S. (2011). The Interview as Collaborative Achievement: Interaction, Identity, and Ideology in a Speech Event. Applied Linguistics. doi: 10.1093/applin/amq027

The Guardian. (2012a). Financial crisis: timeline. Retrieved 21 November, 2014, from http://www.guardian.co.uk/business/2012/aug/07/credit-crunch-boom-bust-timeline

The Guardian. (2012b). UK recession, recovery, then recession: a timeline. Retrieved 21 November, 2014, from http://www.guardian.co.uk/business/2012/apr/25/uk-recession$\underline{\text { recovery-timeline }}$ 
Talk on immigration and employment in the UK.

Triandafyllidou, A. (2000). The political discourse on immigration in southern Europe: a critical analysis. Journal of Community \& Applied Social Psychology, 10(5), 373-389. doi: 10.1002/1099-1298(200009/10)10:5<373::AID-CASP595>3.0.CO;2-R

Van der valk, I. (2003). Right-Wing Parliamentary Discourse on Immigration in France. Discourse \& Society, 14(3), 309-348. doi: 10.1177/09579265030143004

van Dijk, T. (1992). Discourse and the denial of racism. Discourse and Society, 3(1), 87-118. doi: $10.1177 / 0957926592003001005$

van Dijk, T. (2000). New(s) racism: A discourse analytic approach. In S. Cottle (Ed.), Ethnic minorities and the media (pp. 33-49). Philadelphia, PA: Open University Press.

van Dijk, T. A. (2000). Ideologies, racism, discourse: debates on immigration and ethnic issues. In M. Verkuyten \& J. ter Val (Eds.), Comparative perspectives on racism (pp. 91-116). Aldershot: Ashgate.

Verkuyten, M. (2005). Accounting for ethnic discrimination: A discursive study among minority and majority groups members. Journal of Language and Social Psychology, 24(1), 66-92.

Verkuyten, M. (2005). Immigration discourses and their impact on multiculturalism: A discursive and experimental study. British Journal of Social Psychology, 44(2), 223240. doi: $10.1348 / 014466604 X 23482$

Welfare Reform Act 2007. (2007). The National Archives: UK Government. Retrieved 06 July, 2016 from: http://www.legislation.gov.uk/ukpga/2007/5/contents

Wetherell, M., \& Potter, J. (1992). Mapping the language of racism: discourse and the legitimation of exploitation. New York: Columbia University Press.

Whitehead, K. A. (2015). Everyday Antiracism in Action: Preference Organization in Responses to Racism. Journal of Language and Social Psychology, 34(4), 374-389. doi: $10.1177 / 0261927 \times 15586433$ 